\title{
Phraseological Units with the Component "Heart" Expressing Love and Devotion
}

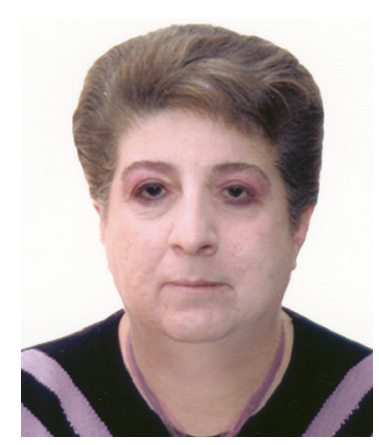

Hasmik Ghazaryan

The heart has long been thought of as the seat of emocentered in the heart? Of course, they are centered in the brain. But when we experience a powerful emotion - fear, anger, grief, love - adrenaline pours into the blood, increases the blood pressure and accelerates the heart. So, it makes perfect sense to think that the heart controls all our thoughts and emotions.

By means of the word "heart" people express their feelings, emotions, wishes, etc. as well as their attitude towards people's behaviour and character.

In different languages the word "heart" may have different symbolic and semantic values. These symbols and meanings can differ from language to language, but quite often they are found to be similar. Sometimes these meanings can undergo certain changes. It should be mentioned that in the course of time not only the meanings of the word "heart" but also those of the abstracted word-groups including this word undergo semantic changes. How and why does this happen?

Based on their centuries-old visual observations and experiences people have always tried to explain the phenomena taking place in a man's organism. Thus for instance, they have noticed that when one is angry he gets black or red in the face, unhealthy people look pale, when experiencing strong fear one's face becomes white and so on. These observations have resulted in the formation of some phraseological units like uмhити ршрша пшпашl, краснеть до корней волос, bluе baby, etc.

But sometimes there has been no opportunity for such observations. In this case people have made mental abstractions and achieved a moral and psychological perception of the phenomena and formed phraseological units such as uhnin Guphl, uhnun thnnhg hшақ, чишақ, покорять сердие, сердие закатилось, affair of the heart, one's heart goes towards sb., etc.

These semantic changes take place by means of certain stylistic devices, such as metaphor, metonymy, hyperbole, simile, etc. It should be noted that as a result of these changes in meaning, the words are transferred into another semantic field.

In linguistics, a semantic field is considered to be an entity of words belonging to different parts of speech but expressing one conception, and it is this very conception that embraces all these words in a given field. Like words, phraseological units can belong to different semantic fields. In this case these linguistic units are placed in these fields according to the whole meaning expressed by their components regardless of their grammatical, structural, stylistic and other peculiarities.

The goal of this paper is to study, analyze and compare the semantic fields of the Armenian, Russian and English phraseological units with the component "heart" 
expressing love and devotion.

What is love? It is one of the most difficult questions for mankind. Centuries have passed by, relationships have bloomed and so has love. But no one can give the proper definition of love. To some love is friendship set on fire, for others love is like luck. You have to go all the way to find it. No matter how you define it or feel it, love is the eternal truth in the history of mankind. Love is patient and devoted, love is kind, benevolent and generous. It isn't envious, nor it boasts itself and it is never proud. It rejoices over the evil and is the truth seeker. Love protects, preserves and hopes for the positive aspect of life. These feelings become the origin of linguistic abstraction by stirring and exciting the soul of a man, thus becoming the source of the phraseological units mentioned above. Here are illustrations of some Armenian, Russian and English phraseological units expressing love and devotion.

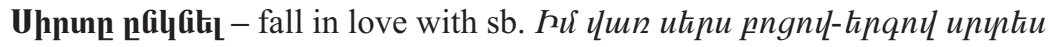
unınug, uһnџn цаңши (Isahakyan I:80).

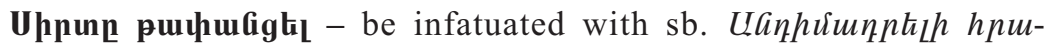
unıрuGpatinny th uhnu tp puтhuGgnıर (Toumanyan I:103): fn-

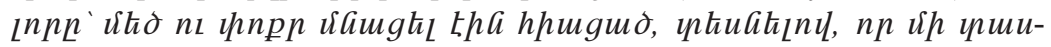

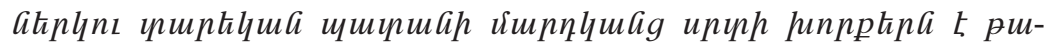
ımaGgnıर (Aghayan:554).

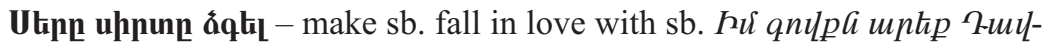
ph шиме, uknu uhnin zqkghp (Toumanyan IV:42).

Upunhfi unpht - fascinate, enthrall sb.'s feelings. Oth uhntiu, who $2 w h$,

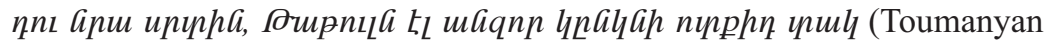

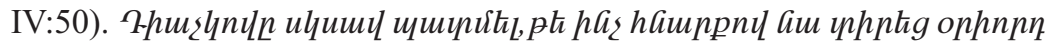

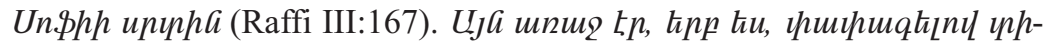

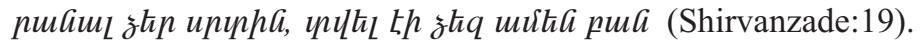

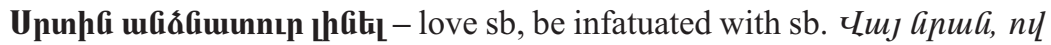

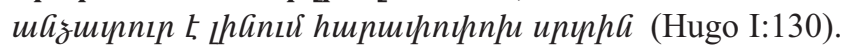

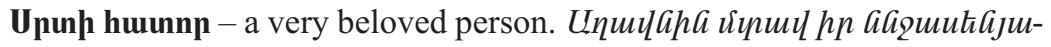

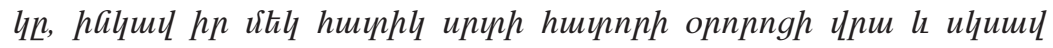
рипупизија циц (Totovents I:256).

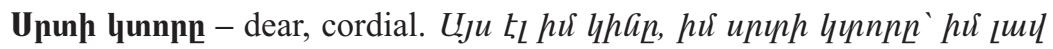
umhiznıln (Torgomyan:480).

Upunp puqnıhp - a sweetheart. 2-nı hu hi uninh papnı2 puqnıhha, Gn-

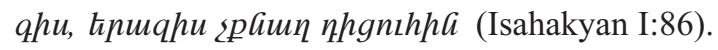


Uhpunn unupugfit - make sb. fall in love with sb. Unı G hul langn

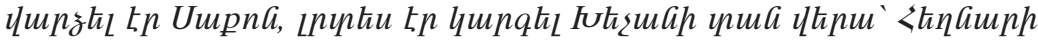

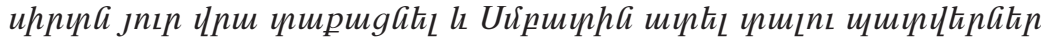
tn тulk (Proshyan:240).

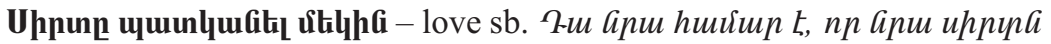

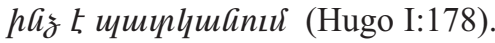

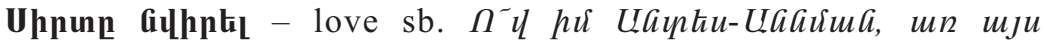

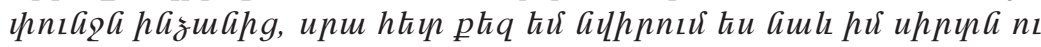
hnqha (Aghayan:550).

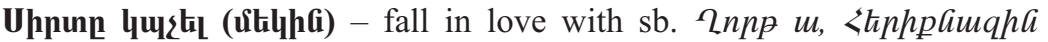

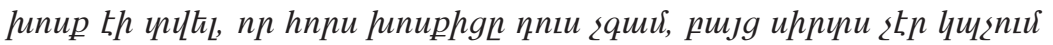

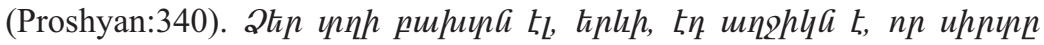

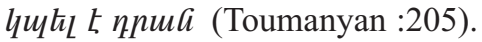

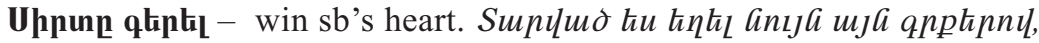

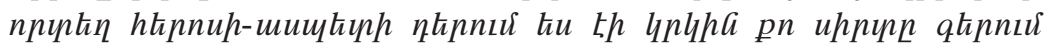

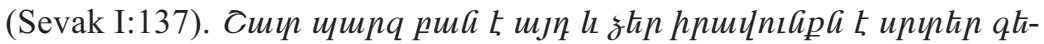
ntil (Hugo III:540).

Uhpunn qpuult - make sb fall in love with sb. Shyhan stn gualquanuर,

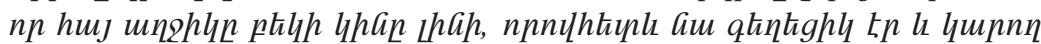

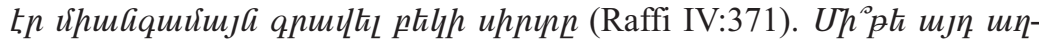

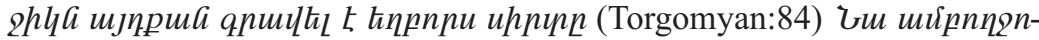

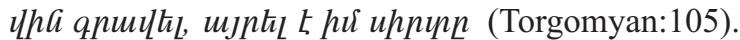

Дама сердца - a sweetheart. На тебе возьми,-прибавила она, бросая Гагину ветку гераниума,-вообрази,что я дама твоего сердиа (Turgenev:19).

Завладеть / овладеть сердцем - win sb.'s heart. Презренные хитрости! прибегать к лукавству, чтоб овладеть сердием женшины!'- с негодованием заметил Александр (Goncharov:136).

Покорять сердце - win sb's heart. На второй же год после её свадьбы с Калатиным, который в несколько дней успел покорить её сердие (Turgenev:4).

Отдавать/отдать сердще - love sb. Другой! Нет, никому на свете Не отдала бы сердие я! (Pushkin:96). 
По сердцу - like sb/sth. Я не могу ошибиться.Ты пришелся ей по сердиу (Turgenev:269). Смирив со временем как знать? По сердиу я нашла бы друга (Pushkin:95). Человек известный, князь, с состоянием, человек хороший и ко всему тому пришелся ей по сердиу (Dostoevski:352).

Absence makes the heart grow fonder (prov.) - Parting makes love stronger.

Give one's heart to sb./sth. -love sb., be devoted to sth. As though to her music she was giving a heart he had never seen (Galsworthy:38).

Lose one's heart (to sb./sth.) - fall in love with sb./sth. I declare I've lost my heart to you already (Cronin:110).

Put heart (and soul) in sth. - have one's whole heart in sth. He had put his heart into that house, indeed (Galsworthy:45). It's not my fault that I haven't been able to put my heart into it (Galsworthy:216).

Set one's heart on sb./sth. - strive for sb./sth., be infatuated with sb., dream of sb. That's a good one, that is, for me that's set my very heart on winning it (Cronin:609). Well it's a mess. She's set her heart upon their boy (Galsworthy:168). Fate had driven him seventeen years ago to set his heart upon this woman-so utterly, that even now he had no real heart to set on any other (Galsworthy:192).

Possess one's heart (Possessor of one's heart) - win one's heart. Bosinney - the one man who had possessed her heart, to whom she had given her whole self with rapture (Galsworthy:341). He stood up and walked about, dreaming his dream of a life continued with this lovely possessor of his heart (Dreiser:289).

Win sb.'s heart - Make sb. fall in love with sb. The grace of this woman had won Carrie's heart (Dreiser:349). Admire his collection of coins, prints and water-color drawings, and you will win his heart (Collins:30).

Studying the phraseological units mentioned above, one can notice that besides their main meaning according to which they are included in this semantic field they posses some other shades of meaning as well. We should mention that some of those shades are peculiar to all the languages under consideration, while others - to one or the other. Thus for instance, the units of all the three languages have the semantic shades of falling in

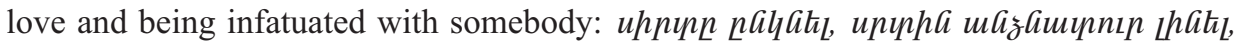

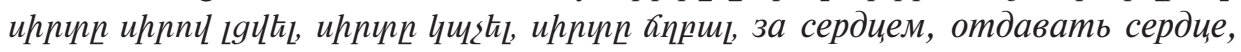
give one's heart to sb, lose one's heart to sb/sth, etc. 
Another shade which can also be found in all the languages considered is possessing somebody's heart, making somebody fall in love with somebody at the cost of great

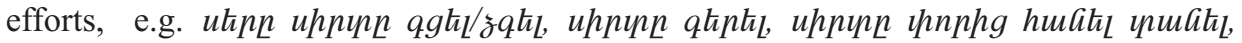
завладеть сердием, покорять сердие, possess/take possession of sb's heart, win sb's heart, etc.

Some units in the mentioned languages express a meaning concerning "the beloved

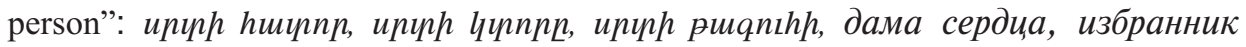
cepdu, the darling of all hearts, etc.

The shade of devotion can be found only in Armenian and English: uhnun nipph zuml qakl Lhakl, have one's heart in sth., put heart and soul in sth., etc.

A number of phraseological units found in the following semantic field are in antonymic relations with the units considered above, i.e. these units possess the meanings of indifference, despair, feeling of not liking or loving, etc. Here are some units with those meanings:

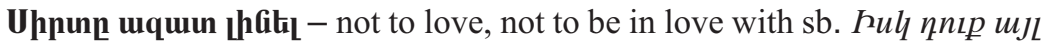
hp, zhn uhnin uqquи 5 (Shirvanzade:59).

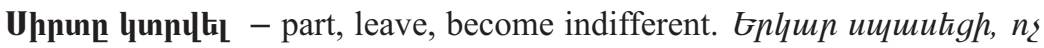

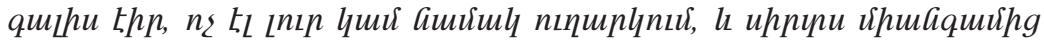
linpykg (Torgomyan:230).

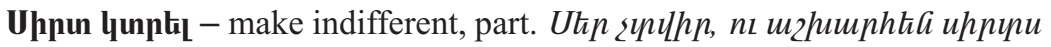
ципиц, Спцша ди а (Isahakyan I:135).

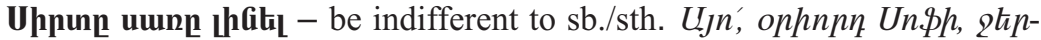

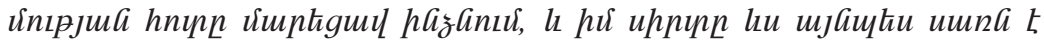

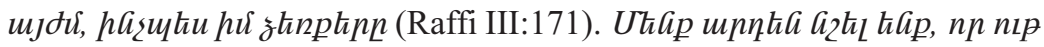

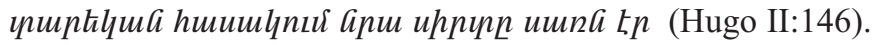

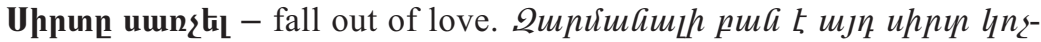

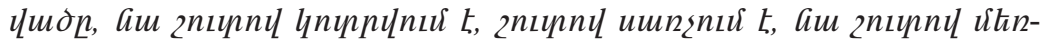

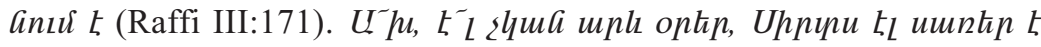
џипnѓg (Isahakyan I:83).

Uhpung uuntigfiti - make sb. indifferent, not to love sb. Ul huqhn,

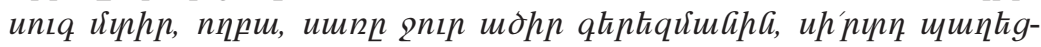
$n n \iota^{\prime}$ (Demirchyan:525).

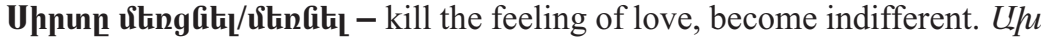

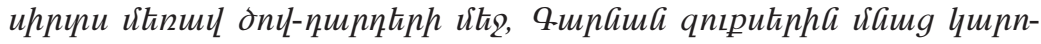
чny (Isahakyan I: 152). 


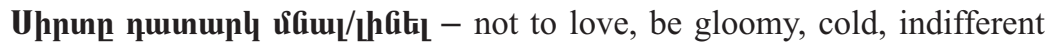

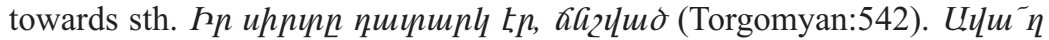

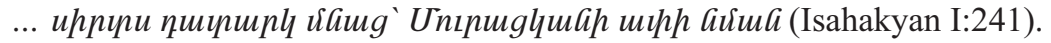

In the following examples too, some semantic shades such as indifference, feeling of not liking, etc. can be found. Thus for instance, the Armenian units uhnчn шquш Lhakl and uhnin quтииl vGul both have the same meaning: the feeling of not loving. Besides this the second unit possesses a shade of pity and bitterness as well. This seman-

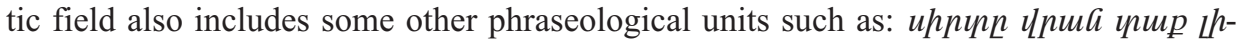

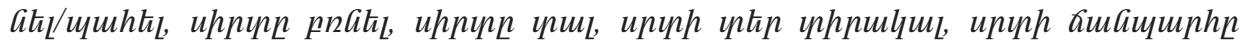

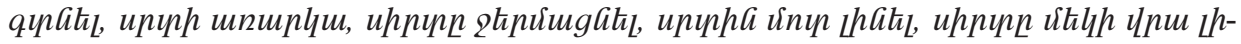

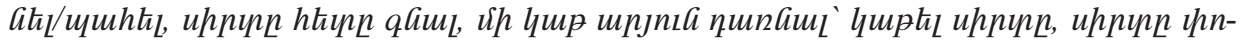

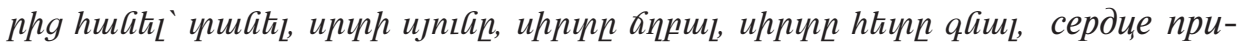
надлежит, войти в сердие, избранник сердиа, за сердцем, находить доступ $\kappa$ сердuy, dear heart, the way to a man's heart is through his stomach, close/near to one's heart, affair of the heart, have a soft/warm corner in one's heart for sb., etc.

Structurally the phraseological units with "heart" belong to different types. Although

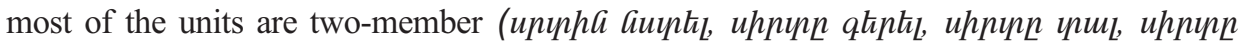
ацикћ, завладеть сердием; покорять сердие; завоевать сердие, etc), three-mem-

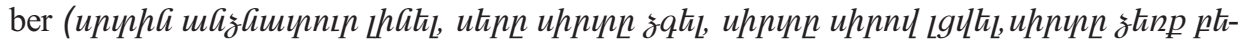

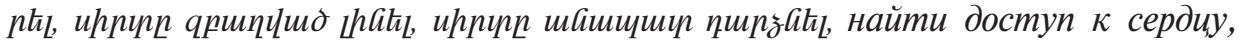
possess one's heart, win one's heart, etc) and multi-member (uhnin thnhhg huahi tru-

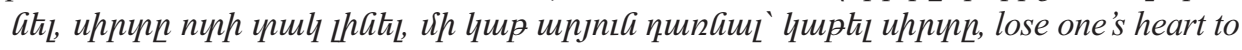
$s$, have a soft corner in one's heart; set one's heart on $s b . / s t h$.) many verbal constructions,

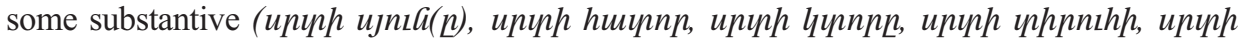
миншцш, дама сердиа; избранник серди, affair of the heart; possessor of one's heart; the darling of all hearts) and modal (серие моё, dear heart) units can also be found. Several complex communicative units are also found (the heart that once truly loves never forgets, the way to the man's heart is through his stomach, nуть к сердиу мужчины проходит

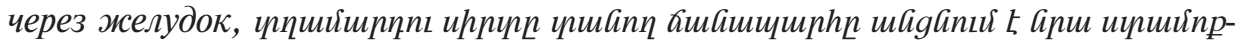
uny: We think that the Russian equivalent of the unit the way to the man's heart is through his stomach has been borrowed from English and the corresponding Armenian equivalent from the Russian one. Some units in Russian such as за сердием; по сердиу; не по сердuy are considered to be "one-top" units.

Several nominal and verbal grammatical categories function in these units. It is not our aim to analyze those categories in detail here. We would like to mention only that some of these categories have a meaning-distinguishing role, and the units would be deprived of their meanings if those categories were used otherwise. The syntactical relations between the components of the units are expressed by the typological peculiarities of the languages under consideration. There are few phraseological variants in the field:

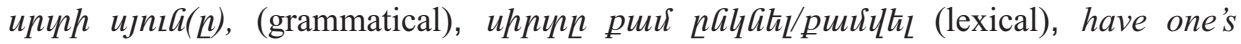
(whole) heart in sth. (quantitative) etc.

Several synonymic rows can be found among the units of this field: 


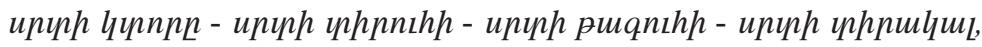

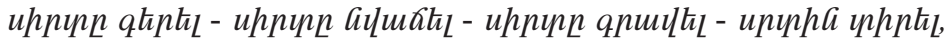

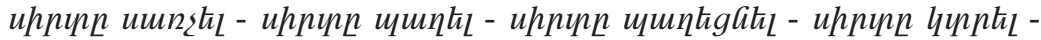

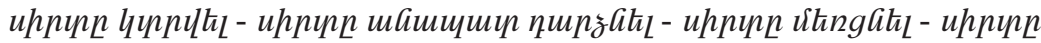

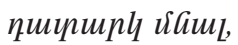

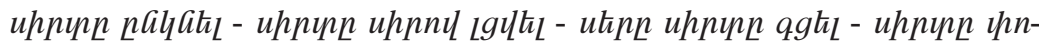

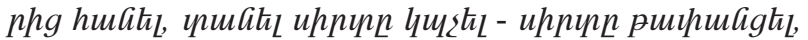

завладеть сердием - завоевать сердие - покорять сердие,

дама сердиа - избранник сердиа,

найти доступ к сердиу - войти в сердие,

give one's heart to sb/sth - lose one's heart to sb./sth. - set one's heart on

sb./sth.,

have one's heart in sth - put heart and soul in sth.,

take possession of one's heart - win one's heart.

There aren't antonymic units within the first and the second groups, but on the whole the units of the first group are in antonymic relations with those of the second group:

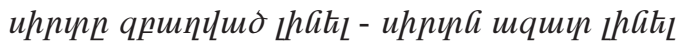

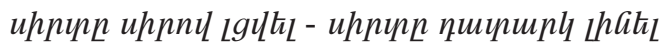

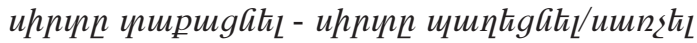

nо сердиу - не по сердиу

have a soft corner in one's heart - the heart hardens.

The phraseological units of this field are used in different functional styles of the language. Some of them are used in colloquial language, one or two - in dialects (in Armenian). Fiction is in fact very rich in them.

The investigation of the phraseological units of this semantic field indicates that some of the units in different languages have their equivalents in one or two languages. These equivalents are mostly both semantic and componential:

ипина тhnћl- завладеть сердием - possess one's/sb. 's heart/take possession of sb. 's heart,

uninh vits vinakl - войти в сердие,

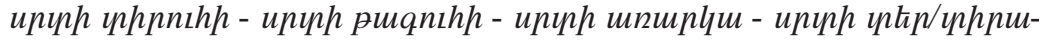
циц - дама сердй - èçáđài í èê ñåđäöà,

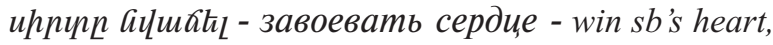

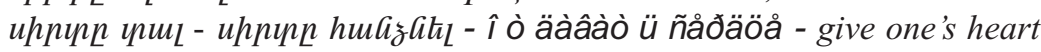
to $s b$,

uhnчn qhitl - покорять сердие, unyha vinin Laki - be close to one's heart, uhnun uшnn Lhall - the heart hardens,

сердие моё-dear heart. 
As we can see there are many similarities and differences between the semantic, structural and grammatical characteristics of the phraseological units studied in the paper. These similarities indicate to commonness and differences, universal features and certain peculiarities typical of the linguistic thinking of different peoples.

\section{Dictionaries:}

1. Brewer's Dictionary of Phrase and Fable. (1956) London: Harper Collins Publishers.

2. Kunin, A.V. (1984) Anglo-russky phrazeologicheski slovar. M.: Russky yazik.

3. Phrazeologicheski slovar russkogo yazika. (1978) Ed. Molotkova A.I. M.: Russki yazik.

4. Sukiasyan, A., Galstyan, S. (1975) Hayots lezvi dardsvatsabanakan bararan. Yerevan: YSU Publishers.

5. Zhamanakakits hayots lezvi batsatrakan bararan (1969 -1980) Yerevan: ASRA Publishers.

\section{Sources of Data:}

1. Aghayan, Gh. (1979) Yerker. Yerevan: Sovetakan grogh.

2. Collins, W. (1934) The Woman in White. UK: Chapman and Hall.

3. Cronin, A.J. (1963) Hatter's Castle. M.: FL Publishers.

4. Cronin, A.J. (1957) The Citadel. M.: FL Publishers.

5. Demirchian, D. (1987) Vardanank. Yervan: Luys.

6. Dostoyevski, F.M. (1981) Idiot. M.: Pravda.

7. Dreiser, Th. (1968) Sister Carrie. M.: FL Publishers.

8. Galsworthy, J. (1955) To Let. M.: Progress Publishers.

9. Galsworthy, J. (1955) In Chancery. M.: Progress Publishers.

10. Galsworthy, J. (1955) The Man of Property. M.: Progress Publishers.

11. Goncharov, I.A. (1968) Obyknovennaya istoria. M.: Khudozhestvennaya literatura.

12. Hugo, V. (1987) Tshvarner. Yerevan: Luys.

13. Isahakyan, A. (1973) Yerkeri zhoghovatsu. Vol. I. Yerevan: Hayastan.

14. Proshyan, P. (1968) Hatsi khndir. Yerevan: Hayastan.

15. Pushkin, A.S. (1982) Poemy. M.: Khudozhestvennaya literatura.

16. Raffi, (1984) Yerkeri zhoghovatsu. Vol. I, II, III. Yerevan: Sovetakan grogh.

17. Sevak, P. (1968) Yerkeri zhoghovatsu. Vol. I. Yerevan: Hayastan.

18. Shirvanzade, A. (1950) Yerkeri liakatar zhoghovatsu. Vol. VI. Yerevan: Pethrat.

19. Shirvanzade, A.(1995) Chaos. Yerevan: Luys.

20. Turgenev, I.S. (1979) Tri vstrechi. Leningrad: Khudozhestvennaya literatura.

21. Turgenev, I.S. (1952) Dvoryanskoye gnezdo. M.: Khudozhestvennaya literatura.

22. Turgenev, I.S. (1977-78) Sobraniye sochineniy. Vol. V. M.: Khudozhestvennaya literatura. 
23. Toumanyan, H. (1990-1996) Yerkeri liakatar zhoghovatsu. Yerevan: ASRA Publishers.

24. Torgomyan, Ts., (1959) Anmar krakner. Yerevan: Haypethrat.

25. Totovents, V. (1988) Yerker. Yerevan: Nairi.

26. Zoryan, S. (1960) Yerkeri zhoghovatsu. Vol. I, II. Yerevan: Hayastan.

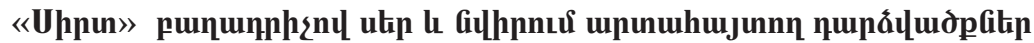

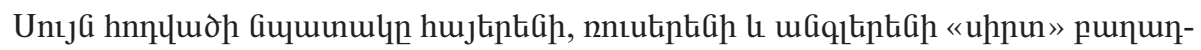

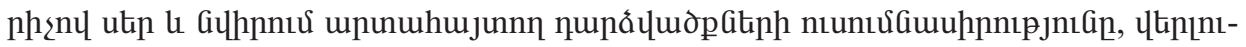

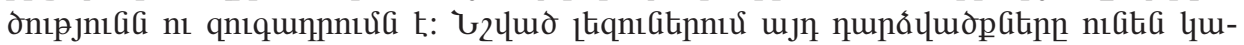

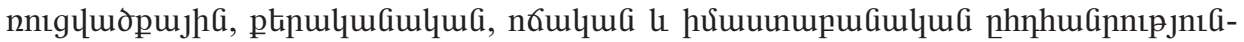

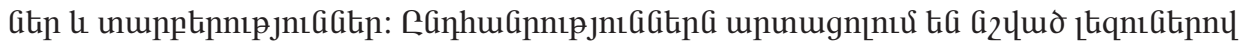

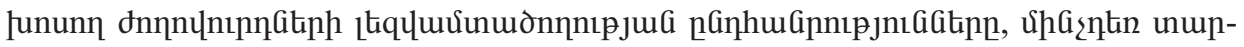

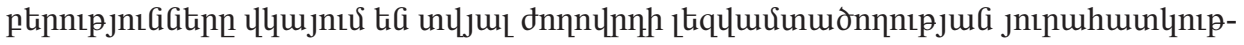
jniGitiph úuuha: 